Vol. 9 (2): 265-274 (2019)

\title{
OXIDE DISPERSION STRENGTHENED STEELS AS CANDIDATE STRUCTURAL MATERIALS FOR NUCLEAR AGGRESSIVE ENVIRONMENTS
}

\author{
Antonino Meli ${ }^{12}$, Massimo Zucchetti ${ }^{1}$ \\ ${ }^{1}$ Politecnico di Torino $\cdot$ DENERG - Department of Energy Italy $\cdot$ Turin, Piedmont, Italy; \\ ${ }^{2}$ Nuclear Professional School, School of Engineering, The University of Tokyo, 2-22 Shirakata Shirane, Tokai,
} Ibaraki 319-1188, Japan;

*Corresponding author Massimo Zucchetti, e-mail: antonino.meli@polito.it; massimo.zucchetti@polito.it;

Received April 2019; Accepted April 2019; Published May 2019;

DOI: https://doi.org/10.31407/ijees9206

UOI license: http://u-o-i.org/1.01/ijees/64575685

\begin{abstract}
In this paper, a description of the past and present research activities for the development of the Oxide Dispersion-Strengthened (ODS) Steels will be carried out, showing why ODS steels are considered among the best candidate structural materials in very aggressive nuclear environments: it can find application as material for the cladding in nuclear fast breeding reactors, or in the blanket/first wall of the fusion reactor as well. General information about the anisotropy of its microstructure, its tensile and creep properties, how they result affected by, and also its resistance to irradiation will be provided.
\end{abstract}

Keywords: Oxide dispersion strengthened steel, Anisotropy, Microstructure, Mechanical properties 